ENCYCLOPEEDE Encyclopédie berbère

BERBERE

$2 \mid 1985$

2| Ad - Ağuh-n-Tahlé

\title{
Adya
}

\section{P. Augier}

\section{OpenEdition}

\section{Journals}

Édition électronique

URL : http://journals.openedition.org/encyclopedieberbere/860

DOI : 10.4000/encyclopedieberbere.860

ISSN : 2262-7197

\section{Éditeur}

Peeters Publishers

\section{Édition imprimée}

Date de publication : 1 novembre 1985

Pagination : 141-142

ISBN : 2-85744-209-2

ISSN : 1015-7344

Référence électronique

P. Augier, «Adya », Encyclopédie berbère [En ligne], 2 | 1985, document A60, mis en ligne le 01 décembre 2012, consulté le 25 septembre 2020. URL : http://journals.openedition.org/ encyclopedieberbere/860 ; DOI : https://doi.org/10.4000/encyclopedieberbere.860

Ce document a été généré automatiquement le 25 septembre 2020

(c) Tous droits réservés 


\section{Adya}

\section{P. Augier}

1 Pierre plate, frappée avec deux pierres rondes (tidyarin), et utilisée comme instrument à percussion pour accompagner, au Gourara, les chants de tagerrabt. Dans la plupart des cas, adya et tidyarin sont respectivement une meule et deux molettes.

2 C'est le seul exemple de lithophone actuellement signalé au Sahara algérien. Mais les chanteurs de tagerrabt lui substituent très souvent des verres à thé entrechoqués par paires, ou une bouteille frappée au moyen d'un instrument de métal: cuillère ou couteau.

Bien que le jeu de l'adya se limite à la répétition incessante de l'une de ces formules :

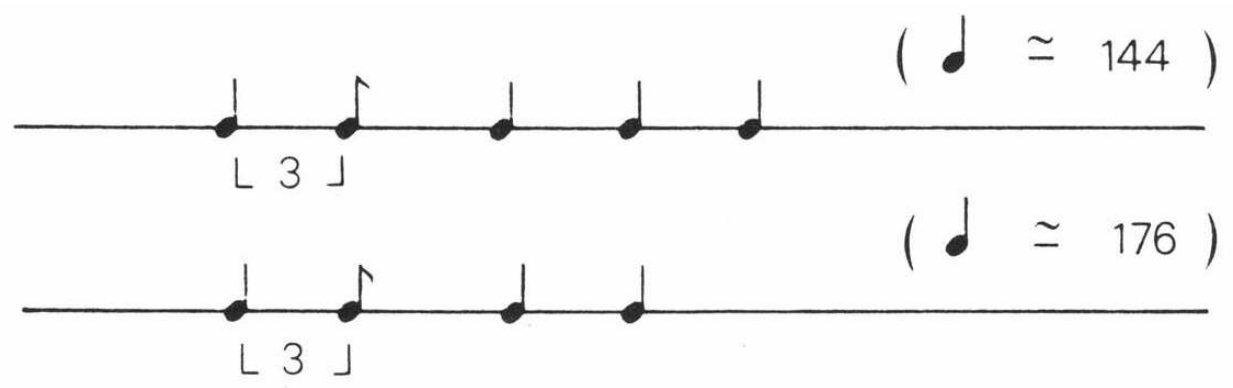

sa fonction est considérée comme importante. Plutôt que de se fier à un musicien peu expérimenté, c'est souvent le chanteur soliste qui joue, s'assurant ainsi la maîtrise du tempo et la direction de l'ensemble. 


\section{AUTEUR}

P. AUGIER

Musique 